\title{
Pit slope evaluation based on the historical failure database at Batu Hijau mine
}

\author{
HD Lelono PT. Newmont Nusa Tenggara, Indonesia \\ FRP Basson Newmont Mining Corporation, Australia \\ J Lupo Newmont Mining Corporation, USA \\ Y Adriansyah PT. Newmont Nusa Tenggara, Indonesia
}

\begin{abstract}
Batu Hijau mine is a large copper-gold open pit mine owned and operated by PT. Newmont Nusa Tenggara. The mine site is located on the southwest of Sumbawa Island in Indonesia and currently approximately 2,000 $\mathrm{m}$ wide and $800 \mathrm{~m}$ deep. Furthermore, the ultimate pit slope design will be more than 2,500 $\mathrm{m}$ wide and $1,000 \mathrm{~m}$ deep.

Over 15 years of operation, Batu Hijau has experienced many pit slope instabilities, ranging from multiple benches to inter-ramp scale. Annually, there are around 20 failures on average and the events continuously recorded in a failure database. A robust failure database is important for further geotechnical analysis and useful for sustainable improvement of the pit slope design.

Slope evaluation is conducted as part of the slope design process and the historical failure database is an important tool for assessing the pit slope performance and for input during the design process. This paper describes an evaluation and assessment of the current slope performance based on the historical failure database. Furthermore, the evaluation aims to evaluate and provide feedback to current mining development and future pit designs.
\end{abstract}

\section{Introduction}

Batu Hijau is a copper-gold mine located in the southwest region of the Island of Sumbawa, in the district of Sekongkang, West Nusa Tenggara Province, Indonesia. The mine is owned and operated by a joint venture company, PT. Newmont Nusa Tenggara (PT. NNT), which is working under a contract of work with the Indonesian government.

Production at Batu Hijau mine commenced on 1 March 2000 and the mine has experienced many slope failures and instability events over the 15 years of active production. The instability events were caused by several factors such as complex geological structures, poor rock mass conditions, high groundwater pressure behind the pit wall, and high precipitation. This paper describes past slope performance, and the lessons will be used to improve the design criteria for future mine development.

\section{Background}

The Batu Hijau open pit mine has experienced many wall failures that are continuously considered during the design process as part of ground control management plan.

\subsection{Climate}

The Batu Hijau open pit is located in a tropical climate and the rainfall is seasonal, with the wet season from November to April and the dry season from May to October. The average annual rainfall is approximately $2,800 \mathrm{~mm}$, with nearly all rainfall occurring during the wet season. 


\subsection{Geology}

The Batu Hijau open pit is dominantly underlain by andesitic volcanic lithic breccia and minor fine-grained volcanic clastic rocks. The rock sequence shows gentle dips and thick to massive bedding. Tonalite porphyry intrusions form a steeply dipping cluster of upward tapering, nearly conical stocks in the centre of the deposit. The old tonalite is limited to narrow remnants along the margins of the intermediate tonalite stock that are only observed from drill cores. The intermediate tonalite comprises the largest part of the main tonalite complex. The young tonalite forms northeast trending vertical dykes of 10 to $20 \mathrm{~m}$ wide that intrude the intermediate tonalite. Intrusive breccias are common along the margins of the intermediate tonalite and occur, less frequently around the young and old tonalites.

The volcanic-diorite contact hosts the intrusive tonalites of which several phases have been identified. The older tonalites are grouped with the intermediate tonalite since it is impossible to differentiate the tonalite phases without microscopic examination. The young tonalite is 'dyke-like', oriented approximately north-northeast to south-southwest and is sub-vertical. The intermediate tonalite surrounds the young tonalite and geometrically somewhat similar to an inverted cone. The rock type distribution is shown on the Batu Hijau geological map in Figure 1.

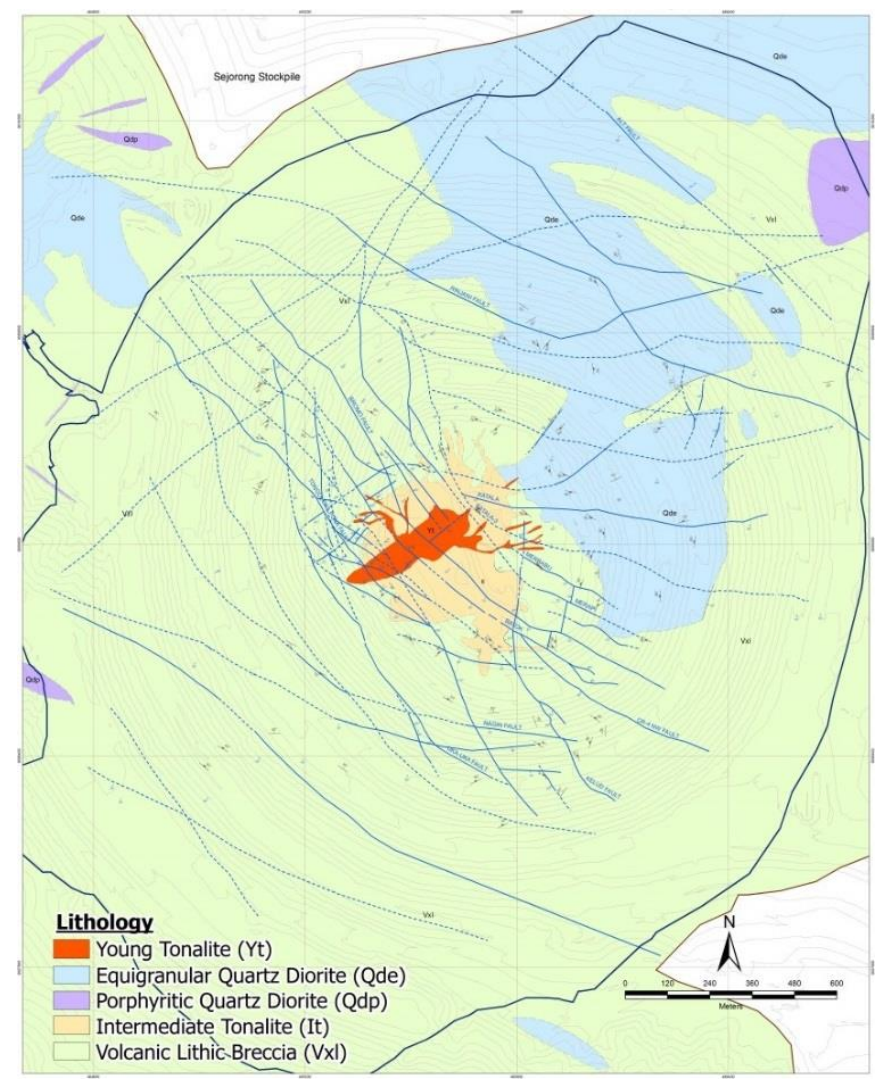

Figure 1 Geological map showing the rock type distribution at Batu Hijau mine

\subsection{Mining}

Development of the Batu Hijau open pit is achieved by conventional truck and shovel operations. The primary loading fleet consists of 111 Caterpillar 793C trucks and seven electric rope shovels. From a geotechnical perspective, two hydraulic excavators are dedicated to wall trimming and scaling, with three drill rigs for drilling pre-split holes, and a contracted drill rig for completing in-pit horizontal drains for wall depressurisation. Artificial ground support is applied in selected areas when required.

The Batu Hijau open pit was developed and mined in a concentric fashion. In general, simultaneous mining was carried out in two or even three phases with the associated interactions. For example, currently phases 6 and 7 are being mined, as shown in Figure 2 . 


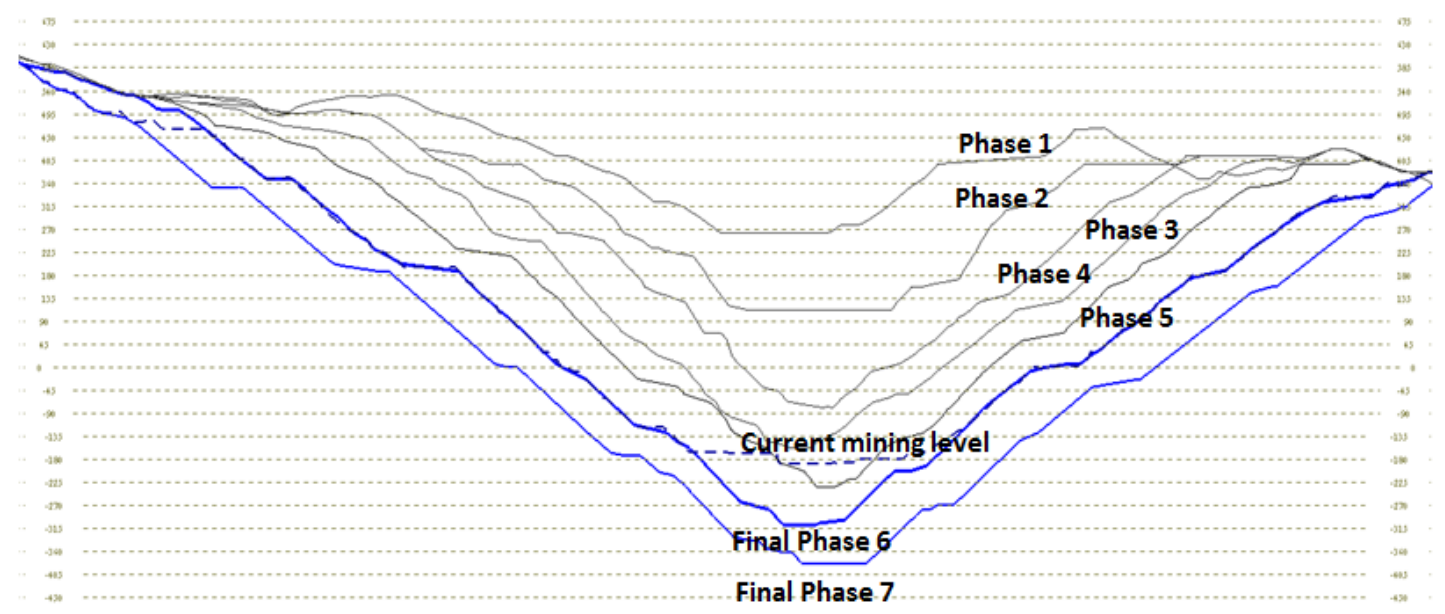

Figure 2 A cross-section showing Batu Hijau mining phases from phase 1 to current mining level

\subsection{Ground control management plan}

As described in the Batu Hijau ground control management plan, the pit slope design philosophy is one of slope management rather than designing slopes that will not fail (Leech 2007). The mine accepts the potential of slope instability, as long as they are operationally manageable at an acceptable level of risk. As a result, Batu Hijau mine has experienced more than 325 failure events over a 15-year operating period.

The evaluation of experience-based slope performance allows the geotechnical department to assess the acceptability of final pit slope designs. As part of the ground control management program, evaluation of the historical slope performance is required. The design process that involved the historical slope performance can be seen in Figure 3. Moreover, a failure report is generated for each slope failure, including the propagation or extension of any failure. Furthermore, all the failure reports are stored in a geotechnical database for easy access by anyone on site.

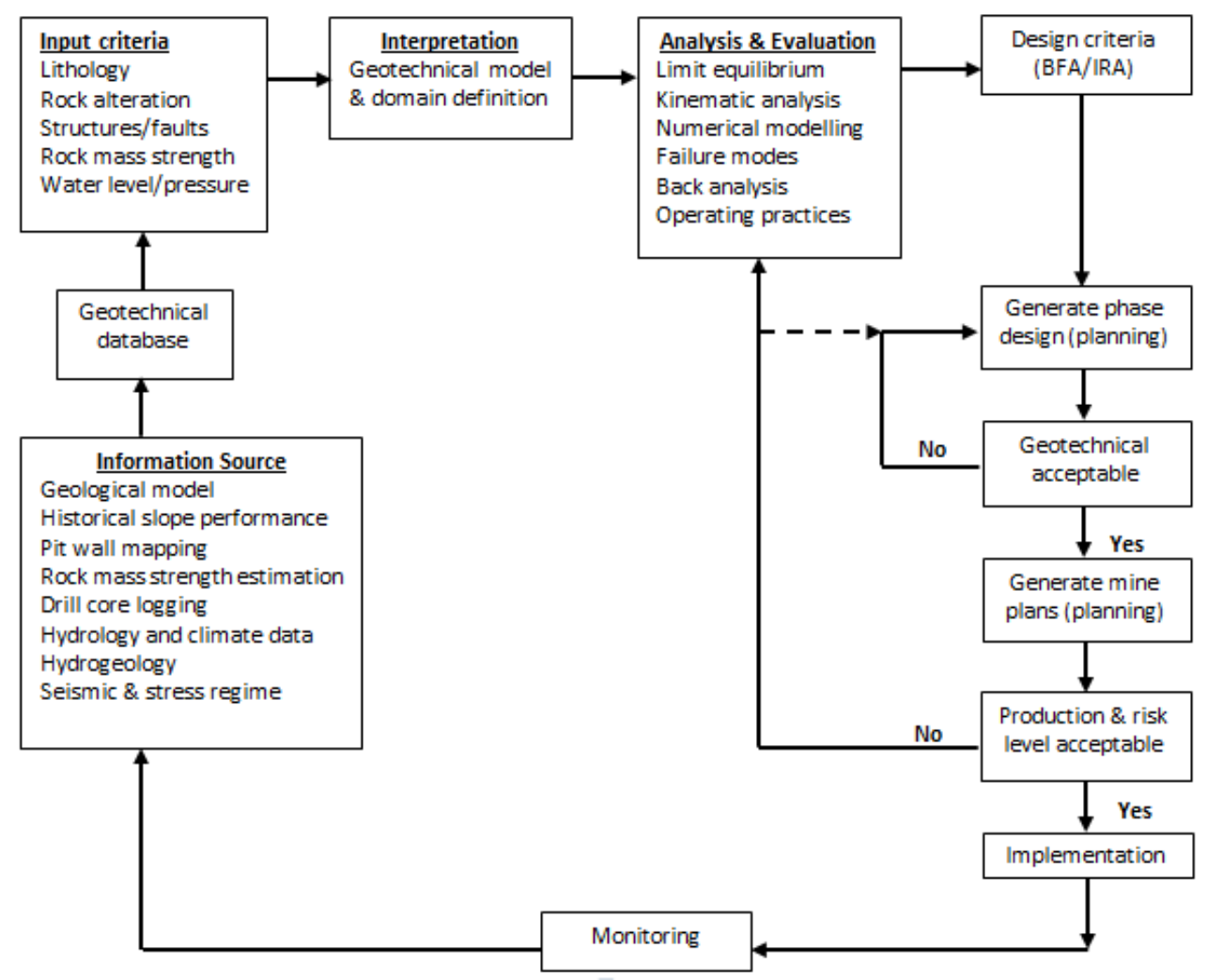

Figure 3 Batu Hijau pit slope design flow diagram 


\section{Geotechnical model}

Batu Hijau has developed a major and intermediate structure model, geotechnical domain model, and wall failure database and each aspect is described in the following sections.

\subsection{Major and intermediate structure model}

In general, there are three main structures mapped in the Batu Hijau pit; namely the Katala, Kelud and Tongoloka Puna faults. The Katala and Tongoloka Puna faults are sub-vertical and strike northwest, forming boundaries to a concentrated faulting corridor (called the 'fault corridor'). In this area, faults are spaced approximately $50 \mathrm{~m}$ apart and have continuity across the pit wall. Although less frequent, there is also a minor orthogonal fault set.

For geotechnical analysis purpose, 3D triangulations of major and intermediate faults are continuously updated. To date, 31 major structures and 18 intermediate structures have been modelled. Figure 4 shows the geotechnical structure map for January 2016.

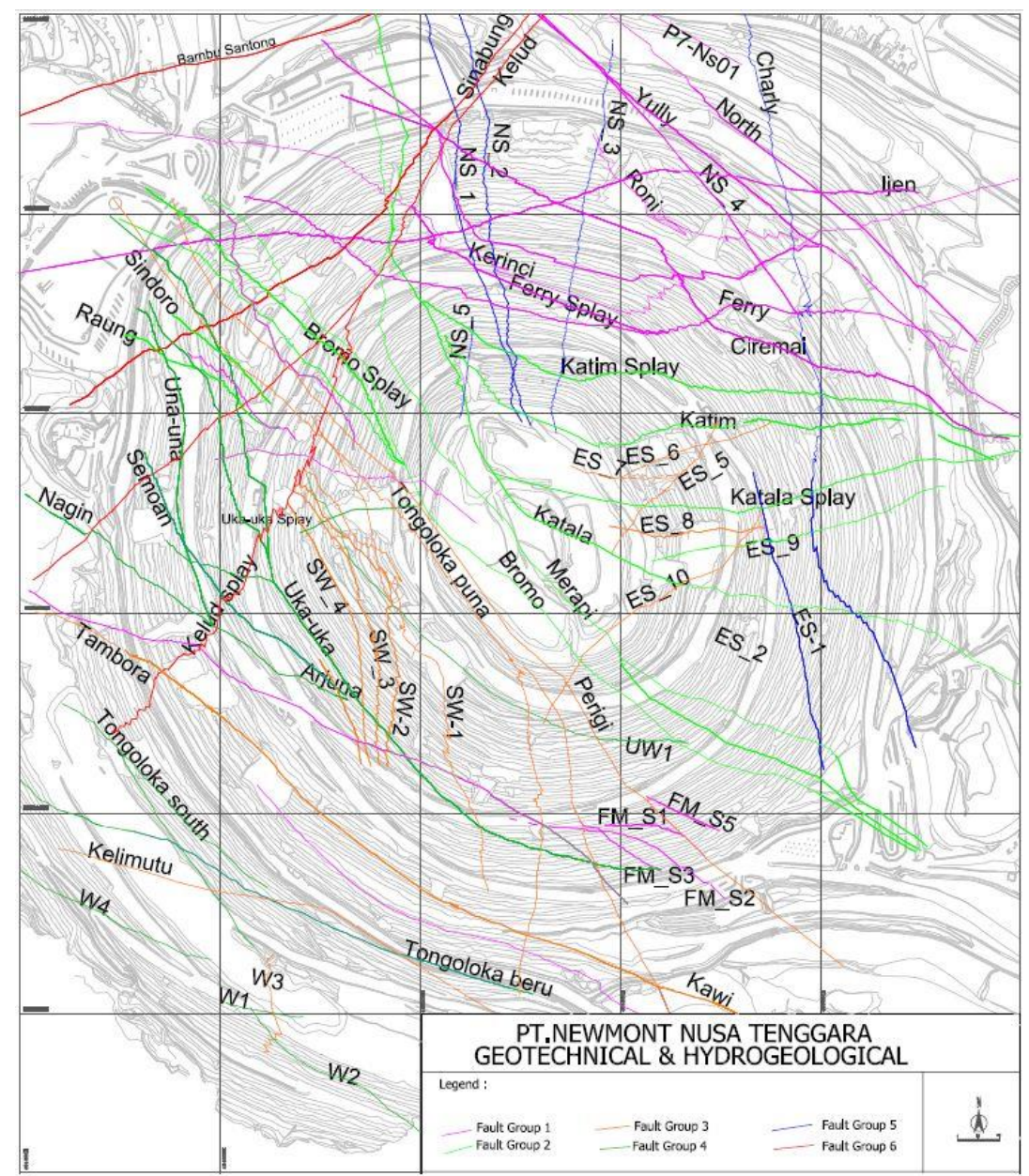

Figure 4 The map of structural geology at Batu Hijau pit updated on January 2016

\subsection{Geotechnical domain model}

As part of the sustainable design process, a geotechnical domain model has been generated and the rock mass characterised on the structural controls, rock fabric, and rock mass classification. Based on the latest data, nine geotechnical domains have been identified with the boundaries generally defined by lithology contacts and the five major faults Bromo, Katala, Katim, Tongoloka Puna, and Tambora. A summary of geotechnical domain characteristics are described in Table 1 and the geotechnical domain model is shown in Figure 5. 


\begin{tabular}{|c|c|}
\hline $\begin{array}{c}\text { Geotechnical } \\
\text { domain }\end{array}$ & Characteristics \\
\hline Domain 1 & $\begin{array}{l}\text { Predominantly diorite with pale green mica (PGM) alteration. In the lower part of this } \\
\text { domain was observed volcanic rock. The slope orientation in domain } 1 \text { is sub-parallel to } \\
\text { major faults. Joint fabric dips toward the pit and perpendicular to the south-southwest } \\
\text { dipping slope face. }\end{array}$ \\
\hline Domain 2 & $\begin{array}{l}\text { Predominantly consists of volcanic rock with secondary biotite alteration. The major } \\
\text { faults trend almost parallel to slope. The joint sets dip toward to the pit and also } \\
\text { perpendicular to the slope face dipping to south-southwest. }\end{array}$ \\
\hline Domain 3 & $\begin{array}{l}\text { Predominantly exposes volcanic rock with PGM alteration. In the current phase } 6 \text { wall, } \\
\text { feldspar destructive alteration was observed in the upper part of the wall inside the } \\
\text { PGM alteration. Major faults trend perpendicular to slope face. The rock fabric } \\
\text { (jointing) generally strikes parallel to the slope and dips toward the pit. }\end{array}$ \\
\hline Domain 4 & $\begin{array}{l}\text { The lithology is predominantly diorite with PGM alteration. The top part of this domain } \\
\text { is dominated by feldspar destructive alteration. The major faults and its splays trend } \\
\text { perpendicular to the slope face and the joint set trending to the northwest. }\end{array}$ \\
\hline Domain 5 & $\begin{array}{l}\text { Domain } 5 \text { is part of central fault corridor. The lithology within this domain is } \\
\text { predominantly volcanic rock with PGM alteration in the upper part and secondary } \\
\text { biotite in the lower part. The major faults trend perpendicular to the slope face. The } \\
\text { joint set trends to north-northwest and dips are shallow to vertical. }\end{array}$ \\
\hline Domain 6 & $\begin{array}{l}\text { The predominant lithology is volcanic rock with PGM alteration in the lower part and } \\
\text { chlorite-epidote in the upper part. Most of the major faults exposed dip into the pit } \\
\text { wall, however there are a few major structures that dip steeply toward the pit. This } \\
\text { domain is characterised by a persistent joint set dipping towards the pit. }\end{array}$ \\
\hline Domain 7 & $\begin{array}{l}\text { The predominant lithology is volcanic rock with PGM alteration in the lower part and } \\
\text { chlorite-epidote in the upper part. Most of the major structure dips into the wall, with a } \\
\text { few major structures dipping steeply toward the pit. Domain } 7 \text { is characterised by a } \\
\text { persistent high-angle joint set that dips towards the pit. }\end{array}$ \\
\hline Domain 8 & $\begin{array}{l}\text { Domain } 8 \text { is part of central fault. The predominant lithology is volcanic with PGM } \\
\text { alteration in the upper part and secondary biotite in the lower part. Major faults trend } \\
\text { perpendicular to slope face. The dominant rock jointing is parallel to the pit wall, which } \\
\text { dips steeply to the east-northeast. }\end{array}$ \\
\hline Domain 9 & $\begin{array}{l}\text { Predominantly composed of intermediate and young tonalite with secondary biotite } \\
\text { alteration. The faults strike almost parallel to the slope face, and dip steeply into the } \\
\text { pit. In addition, shallow dipping joints are also present. }\end{array}$ \\
\hline
\end{tabular}




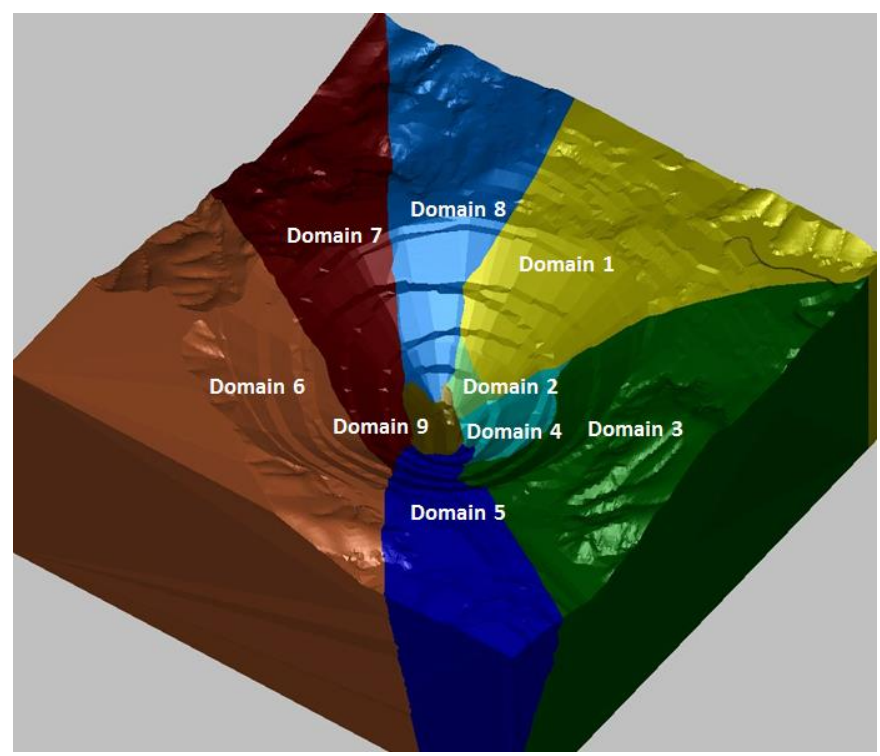

Figure 5 Current geotechnical domain model

\subsection{Failure report and failure block model}

As part of the developing data base of historical slope performance, each failure event is recorded and comprehensively documented in a 'failure register' that has been ongoing since 2001 (Almenara et al. 2011). Each failure report contains detailed information about the failure modes, potential causes of failure, the location and dimensions of the failure, factors that could have influenced the instability, and the orientation and characteristics of the faults and joints involved. Figure 6 shows failure report template.

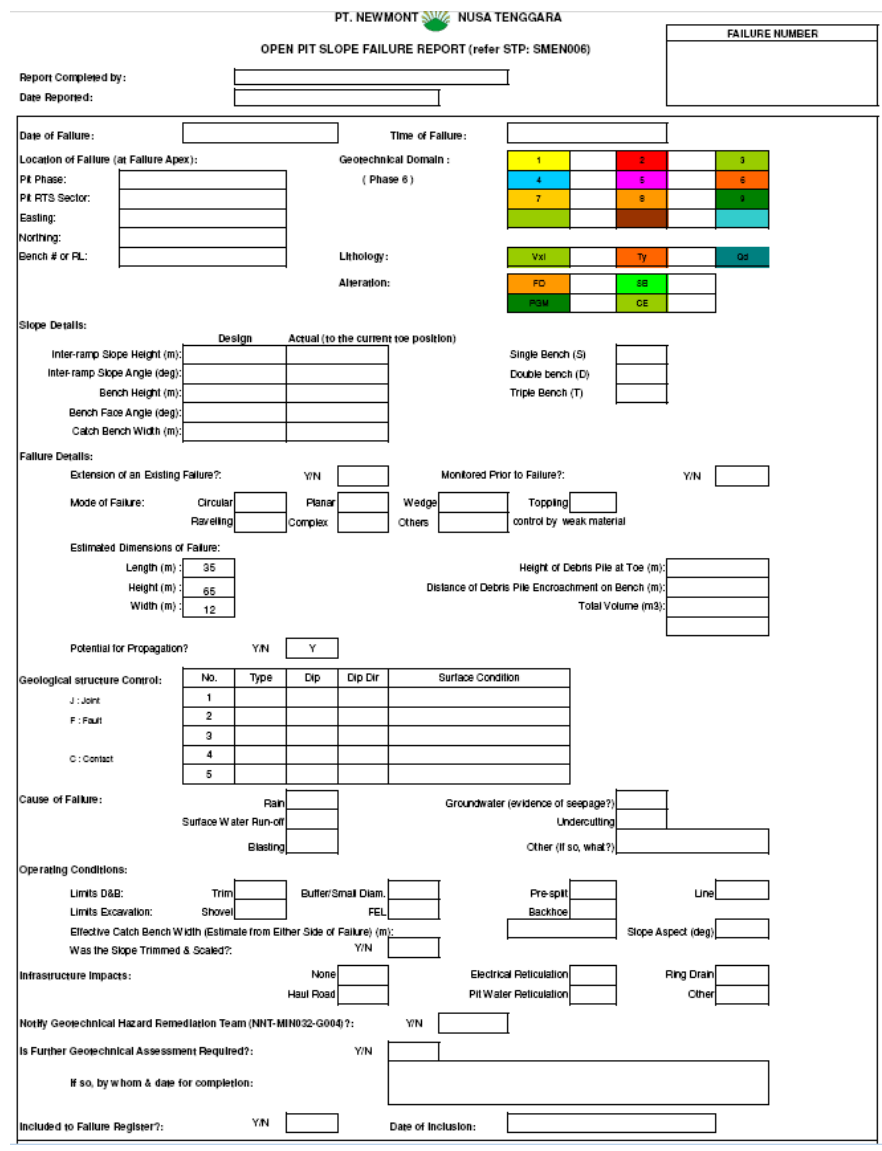

Figure 6 Open pit slope failure report template 
To visualise the failures collectively, a failure block model has been generated as shown in Figure 7. Using the topographic survey of the failure area and the interpreted failure surface underneath, solids of failed material were generated. With Minesight Mining software, 3D blocks were generated that capture the main characteristics of each failure, such as date of failure, slope aspect, orientation of the structures involved, interpreted failure mechanism, geotechnical domain, lithology, alteration, volume, mining phase etc.

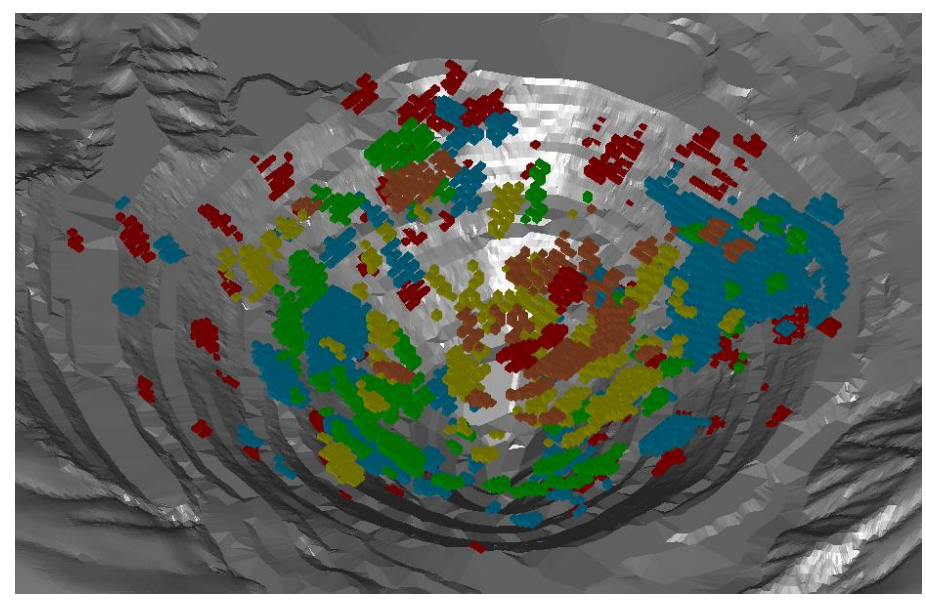

Figure 7 Geotechnical failure block model based on the failure model updated at the end of 2015

\section{$4 \quad$ Historical slope performance and slope design evaluation}

This section describes the historical slope performance and the slope design evaluation, including the implementation of several actions to reduce the slope failure likelihood.

\subsection{Historical slope performance}

This section describes the historical slope failure events at Batu Hijau from 2001 until the end of 2015. The evaluation compares the tonnages of the failures and was sorted on several criteria such as the geotechnical domains, mining phases and seasons.

\subsubsection{Failure distribution and size}

During the period considered, Batu Hijau mine has experienced 325 failure events, which include the propagation, extension and reactivation of existing failures. The total volume calculated from the failure solids is about $11,3 \mathrm{Mm}^{3}$ or 29.35 Mton. See Figure 8 for a summary of the cumulative volume of failure and number of failures.

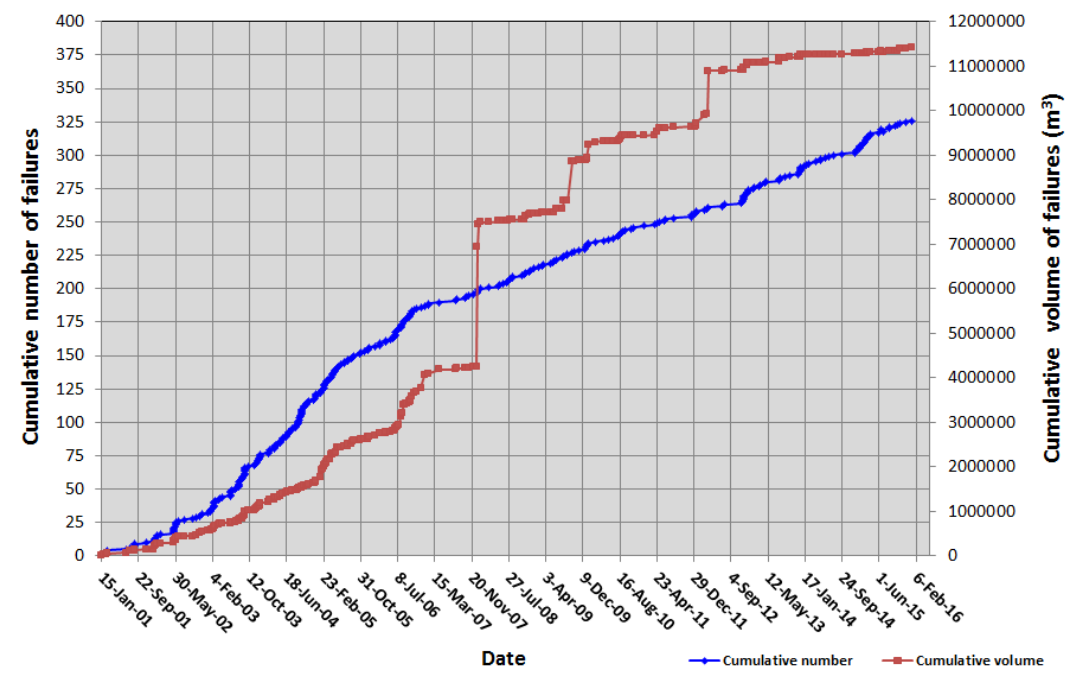

Figure 8 Graph shows comparison between cumulative and total volume of failure 
Based on the size of the slope failure, they were categorised into minor, significant and major failure events. Failure less than $1.5 \mathrm{Kmt}$ was categorised as minor failure, significant failure was ranging from 1.5-150 Kmt, and major failure was more than $150 \mathrm{Kmt}$. The distribution of each failure category as follows:

- Minor is approximately $4 \%$ (13 events).

- Significant is approximately $88 \%$ (286 events).

- Major is approximately $8 \%$ (26 events).

Figure 9 shows the distribution of the number failures in each category.

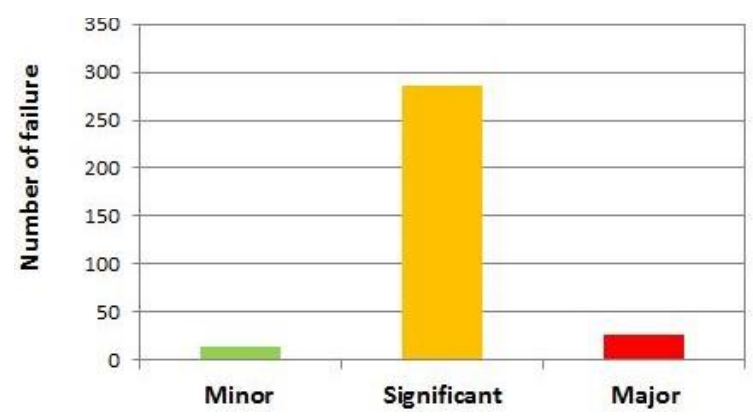

Figure 9 The distribution of failures based on the open pit slope reporting criteria

Based on the failure number, the largest number of failures occurred in the volcanic rock type of domain 7 (Tambora hanging block) with 76 events $(23.4 \%)$. Second was the diorite rock mass of domain 4 (east wall lower block) with a total of 71 failures $(21.9 \%$ ), and third was the volcanic rock of domain 8 (northwest block) with 42 failures (12.9\%). A detailed summary of the total number failures per geotechnical domain is shown in Figure 10.

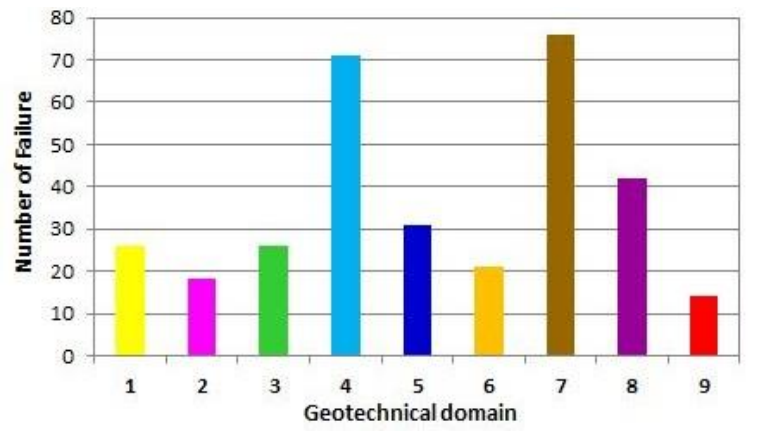

Figure 10 Number of failures per geotechnical domain

Based on the total volume, the largest failure volume occurred in domain 1 (north upper block) with $3.37 \mathrm{Mm}^{3}$ (29.6\%) that was largely contributed by failures 17 and 19 . The failure volume in domain 7 was $2.67 \mathrm{Mm}^{3}$ and came largely from failure 55. The failure volume in domain 4 was $2.24 \mathrm{Mm}^{3}$ and largely from failure 53 . Figures 10 and 11 show the detail for the total number and volume of failure based on geotechnical domains.

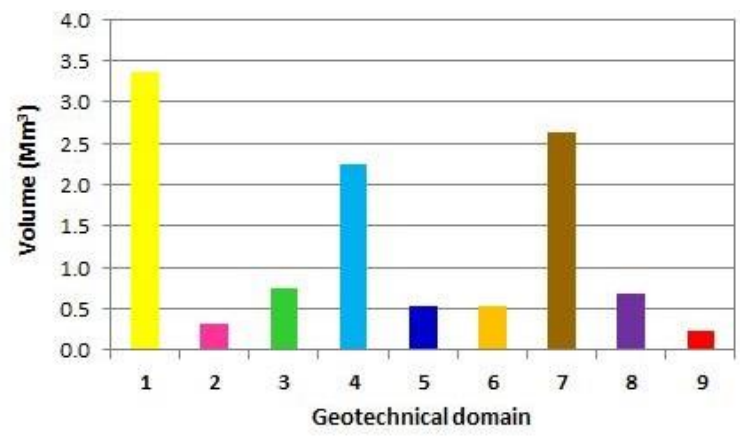

Figure 11 Total volume of failures per geotechnical domain 


\subsubsection{Failure mechanisms - structural influence and the role of water}

The failure database indicated that wedge type failure is the most common with 181 (55.7\%) failure events. Planar failure was less common with 96 (29.5\%) failure events. Other failure mechanisms occurred only occasionally as shown in Figure 12.

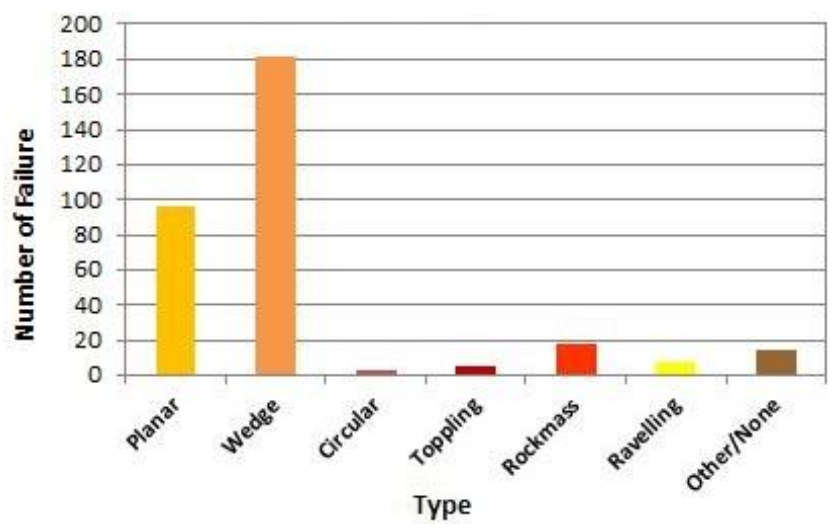

Figure 12 Number of failures by failure type

Historically at Batu Hijau, the wet season (rainy season) occurs from November to April, and the dry season from May to October. Based on failure occurrence, there was no significant difference between the wet and dry seasons in terms of failure number; 159 failures occurred during the wet season and 166 failures occurred during the dry season. This indicates that the slope failures most likely occur due to internal factors, namely the geological structures as described in the previous section. However, the total volume of failure is bigger during the wet season compared to the dry season, with $67.7 \%$ of the total failure volume. The rain fall thus contributes as an external factor that triggered and impacted to the size of the slope failure. Figure 13 shows the total number and volume of failures for the different seasons.

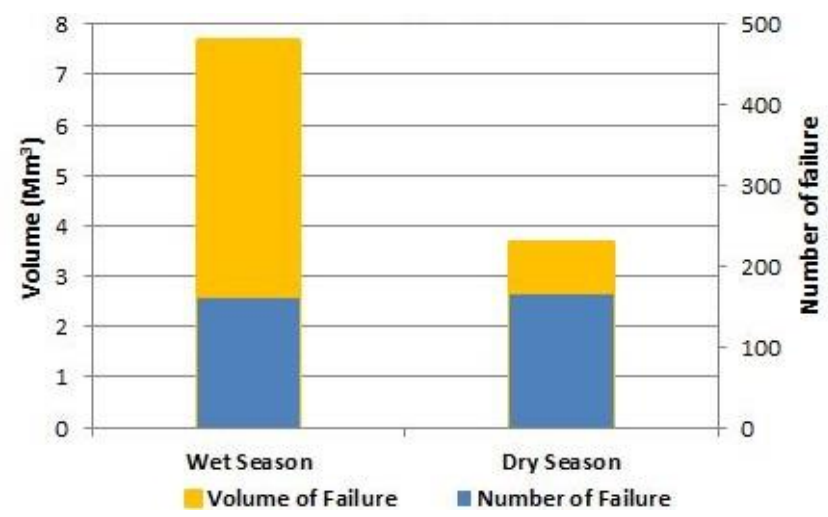

Figure 13 Failures based on season

\subsubsection{Comparing failures between different cutbacks}

Phase 3 showed a significant number of failure events with a total number of 81 failures (24.9\%). Even though the phase 3 mining dimensions were small compared to the current mine shape of phase 6 , phase 3 mining was aggressive by applying 'scram cut' mining. Furthermore, 72 failures occurred during phase 5, and 73 occurred to date in the current phase 6 . The comparison of the total number of failures for each mining phase is shown in Figure 14. 


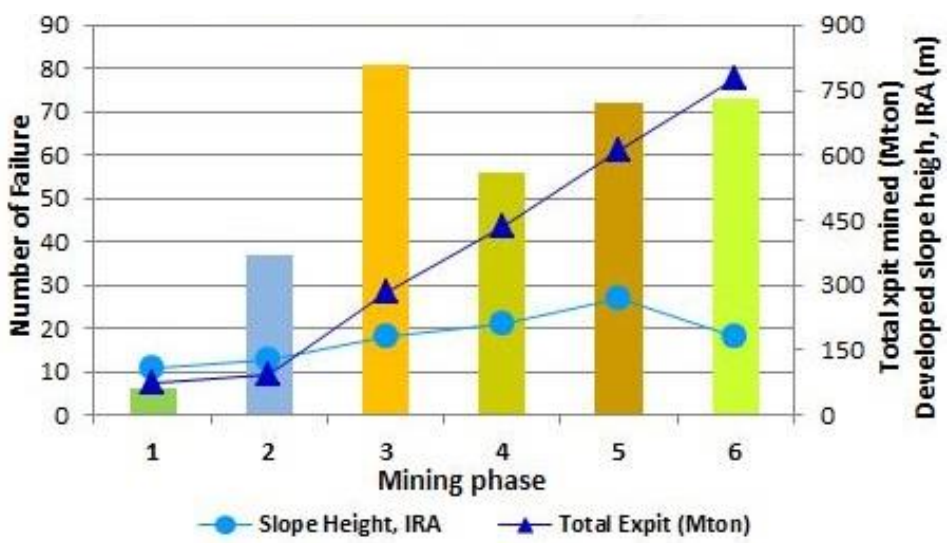

Figure 14 Number of failures based on mining phase

The highest total volume of failure occurred during phase 5 mining with around $7.53 \mathrm{Mm}^{3}(65.7 \%)$. The total failure volume for the current phase 6 mining is low and around $0.66 \mathrm{Mm}^{3}$. The comparison of total number and volume of failure for each mining phase is shown in Figures 14 and 15.

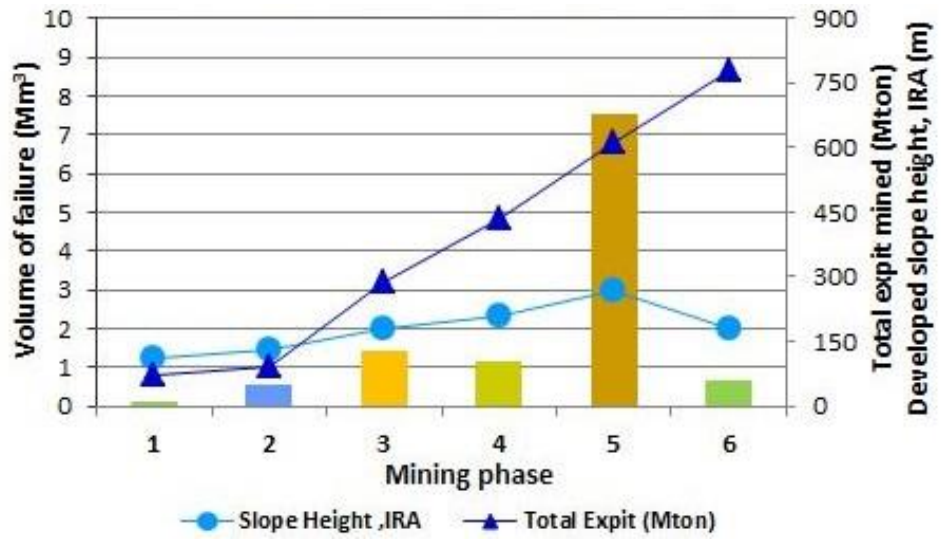

Figure 15 Total volume of failures based on each mining phase

The failure size during phase 6 was controlled by the slope dimension as the highwall slope height was limited less than $150 \mathrm{~m}$. In terms of rock mass quality, there was not a significant change from phase 5 and phase 6 , except in the upper portion of the slope at the west wall.

\subsection{Slope design evaluation}

This section describes the evaluation of slope performance and the mitigation actions implemented. Based on the historical data, failures during phase 5 affected mine production significantly. The main contribution factors were:

- Significant failures occurred during phase 5, namely F\#17\&19, F\#25, F\#53 and F\#55.

- Most of the phase 5 major failures occurred during the wet season (November to April).

- Most of the failures during phase 5 were structurally controlled and were caused by a combination of the major and intermediate structures.

Experience at Batu Hijau indicates that a pit design study analysis of the historical slope performance data was warranted. Considering that the dimensions of phase 6 are bigger than phase 5 , the contributing factors were assessed to mitigate and minimise instabilities during extraction of phase 6 and phase 7 . The mitigation actions and controls were implemented during phase 6 , and further controls will be implemented for phase 7. The implementation of the controls and identified opportunities are discussed in the following section. 


\subsubsection{Decoupling the highwall by implementing the wide catch benches or slope breaks}

Slope breaks and wide catch benches were designed for the areas that experienced major slope failures during previous phases, and the maximum inter ramp height was limited to $150 \mathrm{~m}$. Allowance was made during slope design for these areas to provide 'flexibility room' for in-case instabilities develop. In addition, the slope breaks and wide catch benches can be utilised for infrastructure such as power poles, alternative accesses, surface drainage and geotechnical instrumentation. The decoupling of the highwall is shown in Figure 16.
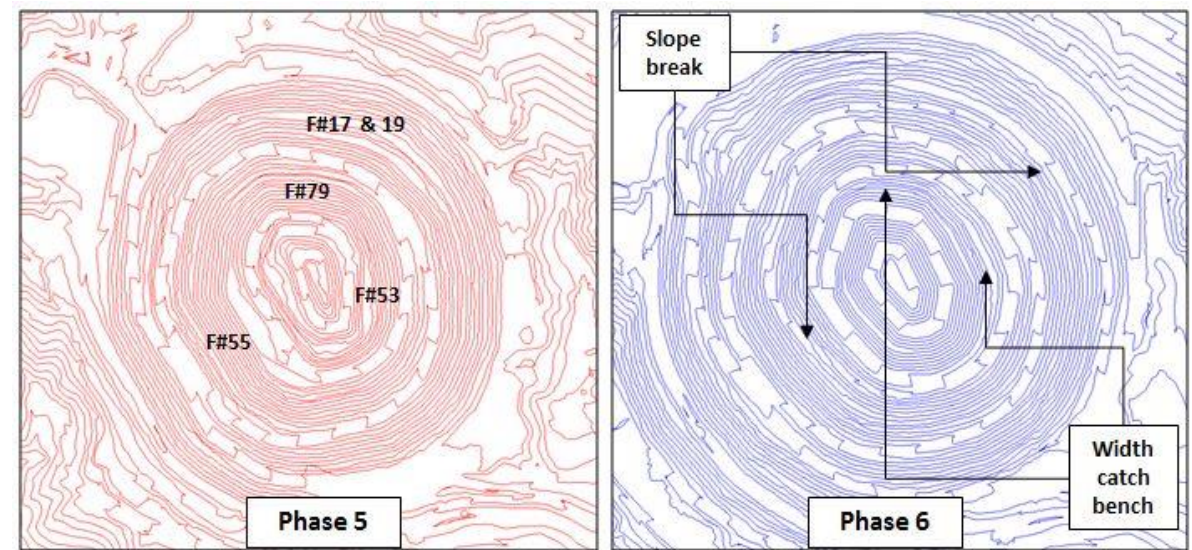

Figure 16 Implementation of slope breaks and wide catch benches in phase 6

\subsubsection{Controlling the surface water}

Batu Hijau mine is mined below sea level, and currently the water level is around $-180 \mathrm{mRL}$ or close to the active mining level. As a result, surface water is one of the major external factors that cause instability events at Batu Hijau mine and a robust surface water management plan is crucial for stability control. Batu Hijau has implemented a surface water management plan to address this issue, particularly before and during the wet season. A coordination team has been established to coordinate surface water management, with members from different mining departments. Secondary sump and continuous surface drainage maintenance are regularly conducted at Batu Hijau.

\subsubsection{Improve the 3D structural model to anticipate instability issues}

Most of multiple bench scale failures at Batu Hijau were structurally controlled by major and intermediate faults, joint sets and rock fabric. Therefore, understanding the faults and defect set orientations are critical to anticipate potential instabilities. A mapping program has been developed to increase the reliability of the structural model, and the model was used to investigate the role of these structures during past instabilities. The major and intermediate fault triangulations can be overlaid onto the failure model to seek potential instability issues on the current or future mine design. An example is shown in Figure 17.
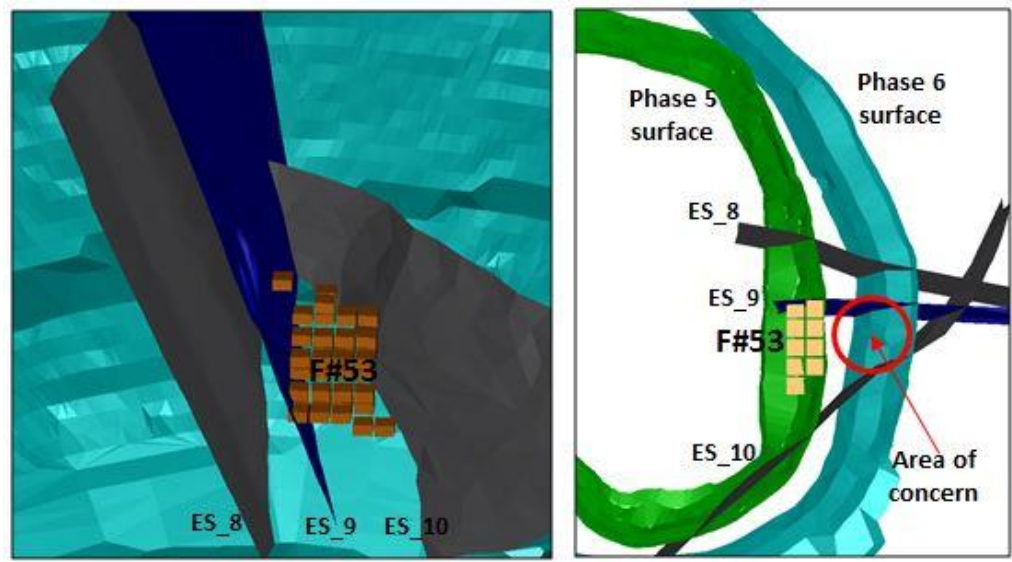

Figure 17 Interpretation of instability issues based on the structural and failure models 


\subsubsection{Opportunity - changing the slope by steepening the inter-ramp angle}

The failure database can be used during back-analysis of previous events, and the learnings can assist with predictions for the next mining phase. For example, using the failure data showed that the failure distribution on the southeast sector of Batu Hijau pit is low. Furthermore, the structural model shows that the major structures are perpendicular to the slope face. As a result, an opportunity could be explored to steepen this southeast sector of the next cut back of phase 7 mining. The simple example of the interpretation process is shown in the Figure 18, but future geotechnical studies and assessments will be conducted.

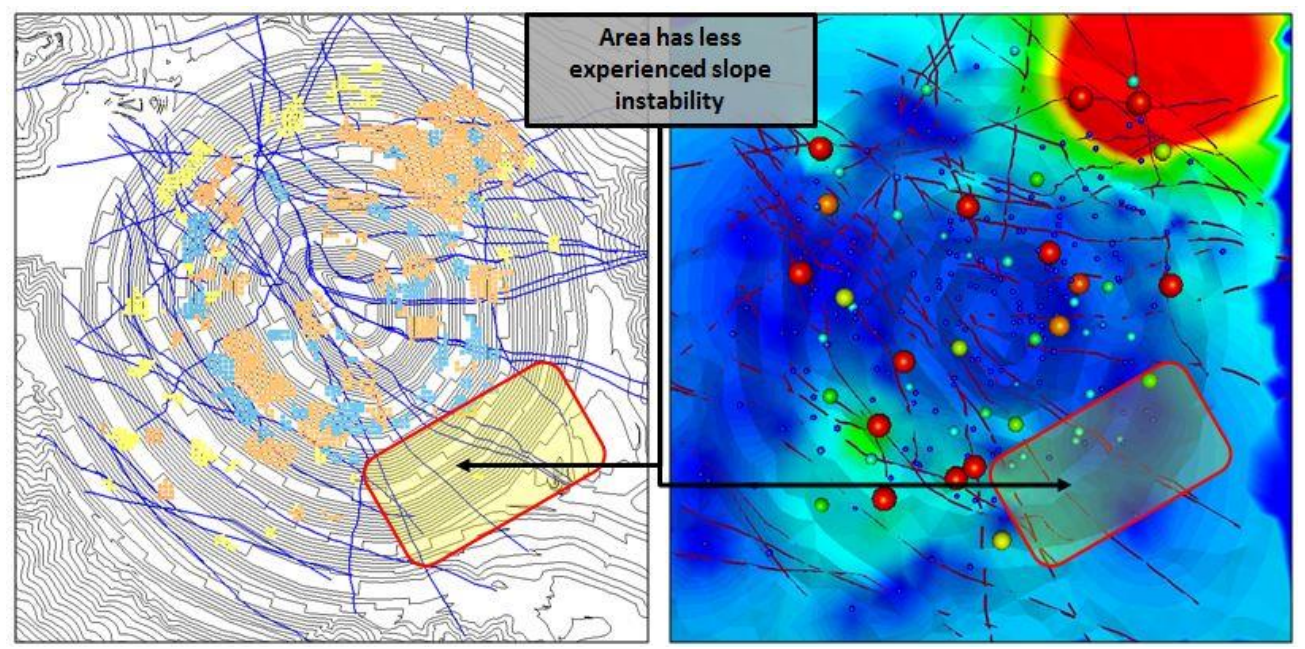

Figure 18 Interpretation failure histories and major faults

\section{Conclusion}

The failure history of past slope performance is part of the pit slope design process. The process aims to evaluate, assess and provide feedback to designs of current and future pit slopes.

Based on the current geotechnical practice at Batu Hijau mine, the failure history for each mining stage is important, and the key to successful improvement of the pit slope design process, and to reduce the likelihood of significant pit wall failures.

Batu Hijau continuously experienced significant failures during extraction of phase 5 , but no major failure event occurred to date during the mining of phase 6 . The implementation of new design criteria such as slope breaks to limit the inter-ramp slope height, and surface water management, has been successful in limiting the failure volumes.

\section{Acknowledgement}

The authors would like to thank the management at PT. Newmont Nusa Tenggara for allowing and supporting the data collection for completion of this paper, and the APSSIM committee for acceptance of this paper. Special thanks to all members of the geotechnical and hydrogeological team.

\section{References}

Almenara, JR, Poespito, TS \& Lelono, HD 2011, 'Batu Hijau Open Pit Slope Design Based on Geotechnical Models and Past Performance', in Proceedings Slope Stability 2011: International Symposium on Rock Slope Stability in Open Pit Mining and Civil Engineering, Vancouver.

Leech, S 2007, 'Establishing Slope design Criteria at Batu Hijau - A Case Study, in Y Potvin (ed.), Proceedings of the International Symposium on Rock Slope Stability in Open Pit and Civil Engineering, Australian Centre for Geomechanics, Perth, Australia. 